\title{
Factors Affecting Responsibility Accounting at Public Universities: Evidence from Vietnam*
}

\author{
Ngoc Tien NGUYEN** \\ Received: February 17, 2020 Revised: March 1, 2020 Accepted: March 6, 2020.
}

\begin{abstract}
The study explores factors that affect the performance of responsibility accounting at public universities in Vietnam. The study conducted a survey of 130, out of 154 public universities in Vietnam and uses regression analysis methods. The results identify eight groups of factors affecting the performance of responsibility accounting at these establishments of higher education: Division of the organization into responsibility centers, Estimation and Reality, Cost and income allocation, University autonomy, Management decentralization, Estimation, Reward, and Report. Costs and income allocation for responsibility centers, university autonomy, and the division of universities into responsibility centers are shown to significantly affect the performance of public universities in Vietnam. The results show that the performance of responsibility accounting at public universities in Vietnam is influenced by decentralization of management, division of the organization into responsibility centers, reward, cost and income allocation, estimation, evaluation of the results achieved between the estimation compared with reality, release of reports and university autonomy. Among the factors, cost and income allocation, university autonomy, division of the organization into responsibility centers, reward and evaluation of results achieved between estimation and reality have strong impacts. The study findings also indicate that the school council does not affect responsibility accounting at these universities.
\end{abstract}

Keywords: Responsibility Accounting, University Autonomy, Financial Accounting, Public University, Vietnam.

JEL Classification Code: M41, M48, G38

\section{Introduction}

This is an empirical study to determine the factors affecting the performance of responsibility accounting (RA) in public universities in Vietnam. To obtain the sample size, the study conducted a convenient sampling and survey with 130 questionnaires, corresponding to 130 public universities out of 154 public universities in Vietnam; the number of valid forms collected is 128 , accounting for $98.46 \%$.

RA needs to be flexible in order to adapt to changes in the legal environment, competition, culture, scale,

*The author would like to thank the anonymous referees for constructive comments on earlier version of this paper.

${ }^{* *}$ First Author and Corresponding Author. Lecturer, Faculty of Economics and Accounting, Quy Nhon University, Binh Dinh, Vietnam [Postal Address: 170 An Duong Vuong, Quy Nhon City, Binh Dinh Province, 55000, Vietnam] Tel: +84 905041179 ,

Email: nguyenngoctien@qnu.edu.vn

(C) Copyright: The Author(s)

This is an Open Access article distributed under the terms of the Creative Commons Attribution Non-Commercial License (http://Creativecommons.org/licenses/by-nc/4.0/) which permits unrestricted noncommercial use, distribution, and reproduction in any medium, permits unrestricted noncommercial use,
provided the original work is properly cited. organizational structure, etc.; therefore, no RA design is normative, but depends on organizational factors or characteristics of the units (Shields, 1995). Some studies have pointed to many factors affecting RA such as firm size (Hoque \& James, 2000), managers' position (Nguyen, 2014), human factor (Horngren, Foster, Datar, Rajan, Ittner, \& Baldwin, 2010; Nyakuwanika, Gumisai, Gutu, Frank, \& Clainos, 2012), self-declaration and attitude (Belkaoui, 1981), legal environment and organizations' characteristics (Nguyen, Nguyen, \& Pham, 2019). At the same time, RA relies on decentralization, standards, measures of performance, appreciation, distribution of rewards, among others factors. Therefore, factors affecting RA have been studied in many fields such as industrial production (Gharayba, Debie, \& Nassar, 2011), hotel business in Jordan (Joda, Sheikh, \& Sbo, 2009), banks operations (Hanini, 2013), enterprises of animal feed processing (Nguyen et al., 2019), to name a few.

Accordingly, in this study, the author will incorporate the factors used in previous studies. At the same time, at qualitative research will be conducted to discover more factors that may affect the RA system and use the data collected at public universities in Vietnam to test whether 
these factors really impact significantly. This study makes a significant contribution to the body of empirical studies about RA in Vietnam calling on the Vietnamese government to be proactive for the purpose of developing general management accounting and RA, in particular.

The structure of this paper consists of five parts. After the introduction, Part 2 is an overview of the study; Part 3 presents the research methods, the hypotheses, the description of research variables and methods of data collection and processing; Part 4 lays out and analyze the research results; Part 5 presents policy implications and conclusion.

\section{Literature Review}

The RA has interested many researchers. Studies from different perspectives have made different judgments; however, the research focuses mainly on the following directions:

Firstly, there is research related to the elements of RA shown in responsibility centers. Garrison and Noreen (2008) suggest that centers of responsibility in financial organizations include Centers of Investment, Centers of Revenues, Centers of Costs and Centers of Profits, and the research suggests that these centers have dialectical relationships with each other, but Centers of Investment plays a key role because, if the investment centers operate well, the right investment decisions will significantly affect Centers of Revenues, Costs and Profits. Joda et al. (2009) show that hotels in Jordan have identified responsibility centers as components that cater to tourists and make estimates clearly, with record and comparison of planned performance to determine the level of RA application to each product, thereby, linking the performance of each part with encouraging employees to work effectively.

When studying the role of RA in the organizational structure, Muthulakshmi (2014) thinks that each part with responsibilities and control tasks will have three basic types of responsibility centers: cost center, revenue center and investment center. Contrary to Muthulakshmi (2014), Horngren et al. (2010) argue that RA includes five responsibility centers: cost center, revenue center, profit center, investment center and gross profit center. The gross profit center is the center of responsibility where the administrator is responsible for the gross profit of that center and the gross profit is calculated by revenue subtracting (-) the variable cost.

With a focusing on Vietnam, Nguyen (2006) studies Vietnam's pharmaceutical manufacturing enterprises, Hoang (2010) examines Vietnamese construction enterprises, Tran (2010) looks at the companies listed in the country, Pham (2010) studied commercial enterprises, Tran
(2015) explores Vietnamese cement manufacturers, among others. Most of these authors have identified responsibility centers including revenue, cost, profit and investment with responsibility reports, and traditional criteria such as return on investment (ROI), return of Investment (RI), etc. The above studies show that, although focusing on many different aspects and researching many different organizations, they all point to a common characteristic which is that research on RA is associated with the responsibility centers of organizations.

Secondly, there is research on the relationship between RA and the enterprises performance. Lin and $\mathrm{Yu}$ (2002) show that companies operating in different socio-economic environments will apply different procedures in the cost control system, including target costs, static cost estimation, flexible cost estimation, internal pricing, performance evaluation and gap analysis. The research shows the influence of RA in improving the cost control system, reducing production costs, motivating employees and helping businesses achieve the set goals. At the same time, Okoye, Ekwezia, and Ngozi (2009) have shown that there is a relationship between RA and achievement in manufacturing enterprises. Since then, the author suggests that the application of RA will help businesses control costs effectively, which will improve profits and the role of managers.

Agreeing with this view, Nguyen (2013) assesses the efficiency and management responsibilities of the responsibility centers associated with the dairy industry in Vietnam. The study also suggests applying a balanced scorecard or economic value added to assess the performance of dairy enterprises in Vietnam. Nguyen (2014) also proposes orientations, establishment and operation of the organizational structure of RA and proposes using some models to evaluate the performance of construction corporations, but stopping at suggestions, not offering modern statistical tools to assess the impact of RA factors on performance. Pham (2010) contends that businesses listed on the stock market benefit from many different aspects, especially the benefit of shareholders.

However, in daily management and administration, only the Board of Directors of the enterprise is the group of representatives to perform the tasks assigned by the shareholders. Therefore, it is necessary to have a tool to help senior managers to monitor and evaluate the management responsibilities of subordinate managers for the assigned work, thereby taking timely corrective actions to improve ineffective activities to accomplish the common goals of the whole enterprise. This shows that the decentralization of management has a great influence on performance. The above studies point to the fact that, in terms of the relationship between RA and performance, the 
application of RA will help the organizations to control costs and, thus, improve the performance.

Thirdly, there is research looking at factors affecting RA. Belkaoui (1981) shows that the division of responsibilities and reward of managers affects RA. Fowzia (2011) indicates that the division of responsibilities, the way to measure the effectiveness of RA and the reward has a significant impact on RA. Nyakuwanika et al. (2012) identify the relationship between the human factor and RA, without the participation of workers in the design of the RA system, it will not be effective. Nguyen et al. (2019) show that management decentralization, division of organization into responsibility centers, cost and income allocation, estimation, estimation and reality evaluation, reporting, reward, legal environment, and business characteristics are the factors that affect the performance of animal feed processing enterprises. The above studies showed that, depending on the operation characteristics of the organization, the factors affecting RA vary. This is also an important basis for the author to carry out this study with the research objective focusing on public universities in Vietnam.

\section{Research Method}

\subsection{Research Process}

To carry out this study, the authors have conducted the various steps shown in Figure 1:

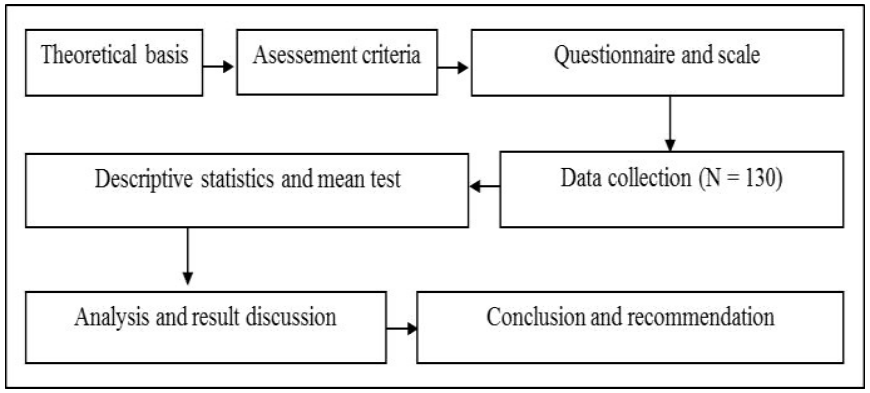

Figure 1: Research process

\subsection{Hypothesis}

\subsubsection{Management Decentralization (MD)}

Decentralization of management is the task of senior managers to delegate decision-making power to subordinate managers in order to evaluate the effectiveness of management and work performance of subordinates for responsibility center assigned management tasks. The studies of Nguyen et al. (2019), Hanini (2013), Gharayba et al. (2011), Joda et al. (2009), Fowzia (2011), and Belkaoui
(1981) show that the decentralization of management affects the RA of organizations.

Hypothesis 1: Management decentralization has a positive relationship with the performance of RA at public universities in Vietnam.

\subsubsection{Divide the Organization into Responsibility Centers (DO)}

The division of an organization into responsibility centers refers to the managers organizing management system of the organization into centers, or units, departments based on its operational characteristics and operation scope of each responsibility center. The studies of Nguyen et al. (2019), Hanini (2013), Muthulakshmi (2014), Gharayba et al. (2011), Tran (2010), Garrison and Noreen (2008), and Nguyen (2006) show that the division of organization into responsibility centers has an impact on the RA work of the organizations.

Hypothesis 2: The division of organization into responsibility centers has a positive relationship with the performance of RA at public universities in Vietnam.

\subsubsection{Reward (RW)}

Reward refers to the rewards for motivating and encouraging employees when workers do their jobs well. Rewarding promptly, accurately, publicly, transparently, the right people and the right jobs are important factors to motivate employees to work and help the organization achieve its set goals. The studies of Nguyen et al. (2019), Nguyen (2014), Hanini (2013), Nyakuwwanika et al. (2012), Gharayba et al. (2011), and Pham (2010) show that the reward has an impact on the private sector work of the units.

Hypothesis 3: Reward has a positive relationship with the performance of RA at public universities in Vietnam.

\subsubsection{Cost and Income Allocation (CI)}

Cost and income allocation is the accountant record of the income generated by the responsibility centers and records, distributing the cost spent to operate the responsibility centers through policies, budget regulations for responsibility centers. The studies of Nguyen et al. (2019), Nguyen (2014), Hanini (2013), Nguyen (2013), Gharayba et al. (2011), Pham (2010), and Lin and Yu (2002) show that the cost and income allocation affects the RA activities of units.

Hypothesis 4: Cost and income allocation has a positive relationship with the performance of RA at public universities in Vietnam. 


\subsubsection{Estimation (EM)}

Estimation is that the managers make operating budgets plans for responsibility centers. Estimation is an important basis for comparing the actual results achieved with the given estimation. The studies of Nguyen et al. (2019), Hanini (2013), Nguyen (2013), Pham (2010), and Lin and $\mathrm{Yu}$ (2002) show that estimation has an impact on the RA activities of units.

Hypothesis 5: Estimation has a positive relationship with the performance of RA at public universities in Vietnam.

\subsubsection{Estimation and Reality (ER)}

Assessment of estimation and reality is that managers use to compare actual results with planned results to responsibility centers in order to identify possible differences to manage performance. The studies of Nguyen et al. (2019), Tran (2015), Hanini (2013), and Hoang (2010) show that the estimation and reality has an impact on the RA activities of the units.

Hypothesis 6: Estimation and reality have a positive relationship with the performance of RA at public universities in Vietnam.

\subsubsection{Report (RP)}

Report is the task of managers of the responsibility centers to make reports to the superiors about the work done as well as the performance of the responsibility centers; the content of the report may include both the financial and non-financial aspects of the responsibility centers. The studies of Nguyen et al. (2019), Tran (2015), Hanini (2013), and Hoang (2010) show that the report affects the RA activities of the units.

Hypothesis 7: Report has a positive relationship with the performance of RA at public universities in Vietnam.

\subsubsection{School Council (SC)}

The school council is the management organization, representing the owners of the School, having the right to decide on strategies, project, development plans and regulations on the organization and operation of the school, its training operation orientation, scientific research, international cooperation. The author has conducted expert interviews for this research and all experts believe that the school council affects the RA of the universities.

Hypothesis 8: The school council has a positive relationship with the performance of the RA at public universities in Vietnam.

\subsubsection{University Autonomy (UA)}

University autonomy is a fundamental element of university administration; autonomy will help universities run better, create motivation to innovate to be more effective in its operations, and also increase competition among higher education institutions, and create conditions for diversifying educational activities. In Vietnam, university autonomy is a university that has the right to autonomy and self-responsibility in accordance with the law on the planning, school development plans, organization of training and scientific activities as well as technology, finance, international relations, organization, and personnel. The author has conducted expert interviews for this study and all experts believe that university autonomy affects the RA of universities.

Hypothesis 9: University autonomy has a positive relationship with the performance of RA at public universities in Vietnam.

\subsection{Research Model}

Based on the research hypotheses, the author proposes that the research model be a multivariate regression model with the dependent variable being the performance of RA at public universities in Vietnam and nine independent variables stated in each hypothesis of the study as shown on Figure 2 .

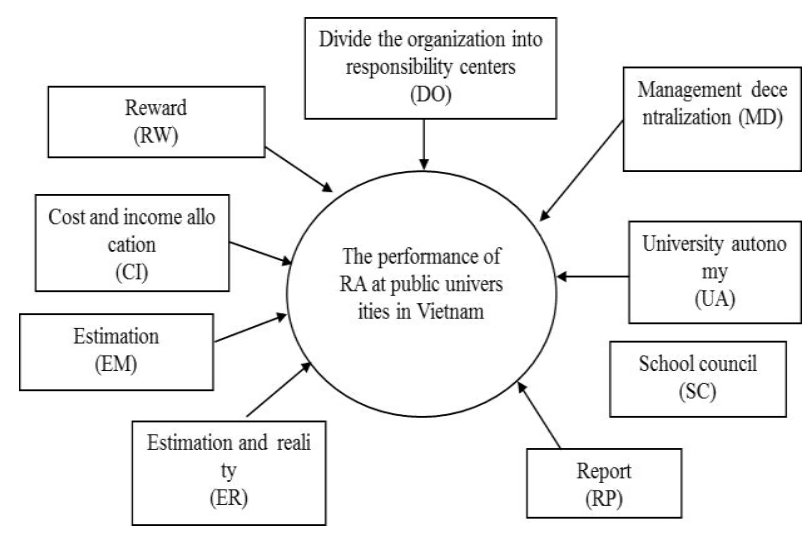

Figure 2: Overview of the research model

From the proposed model, the author propose the reasearch model as below:

$\mathrm{Y}=\alpha+\beta 1 * \mathrm{MD}+\beta 2 * \mathrm{DO}+\beta 3 * \mathrm{RW}+\beta 4 * \mathrm{CI}+\beta 5^{*} \mathrm{EM}+$ $\beta 6^{*} \mathrm{ER}+\beta 7^{*} \mathrm{RP}+\beta 8^{*} \mathrm{SC}+\beta 9^{*} \mathrm{UA}+\varepsilon$

Where: $\alpha, \beta 1, \beta 2, \beta 3, \beta 4, \beta 5, \beta 6, \beta 7, \beta 8$ and $\beta 9$ are coefficients

$\varepsilon:$ is error 


\subsection{Variables of the Research Model}

To serve the process of questioning and answering the survey, the author uses the Likert scale (5 options), the ratings are as follows: 1 = "very low", 2 = "low", $3=$ "average", 4 = "high", 5 = "very high". The variables and scales of the research model are determined as follows (see Table 1):

Table 1: Variables and scales used

\begin{tabular}{|c|c|c|c|c|}
\hline TT & Factors & Observed variables & Encryption & Source \\
\hline \multicolumn{5}{|c|}{ For dependent variable } \\
\hline 1 & \multirow{3}{*}{$\begin{array}{l}\text { The } \\
\text { performance of } \\
\text { responsibility } \\
\text { accounting } \\
\text { (Y) }\end{array}$} & Responsibility accounting work is very effective & Y1 & \multirow{3}{*}{$\begin{array}{l}\text { The author's proposition on } \\
\text { the basis of expert interviews }\end{array}$} \\
\hline 2 & & $\begin{array}{l}\text { Responsibility accounting work is in line with the general trend of } \\
\text { revenue-generating business units }\end{array}$ & $\mathrm{Y} 2$ & \\
\hline 3 & & $\begin{array}{l}\text { Responsibility accounting work following the actual situation at the } \\
\text { University and financial autonomy roadmap }\end{array}$ & Y3 & \\
\hline \multicolumn{5}{|c|}{ For independent variables } \\
\hline \multirow{5}{*}{1} & \multirow{5}{*}{$\begin{array}{l}\text { Management } \\
\text { decentralization } \\
\text { (MD) }\end{array}$} & $\begin{array}{l}\text { 1. The administrative officer at the responsibility center (faculty / } \\
\text { department /institute) is informed of his or her duties }\end{array}$ & MD1 & \multirow{5}{*}{$\begin{array}{c}\text { The author's proposition on } \\
\text { the basis of reference: Nguyen } \\
\text { et al. (2019), Bui (2019), } \\
\text { Hanini (2013), Gharayba et al. } \\
\text { (2011), Joda et al. (2009), } \\
\text { Fowzia (2011), Belkaoui } \\
\text { (1981) }\end{array}$} \\
\hline & & $\begin{array}{l}\text { 2. The administrative officer in the responsibility center (faculty / } \\
\text { department / institute) has the appropriate authority to carry out his work. }\end{array}$ & MD2 & \\
\hline & & $\begin{array}{l}\text { 3. Each job in unit (faculty / department / institute) is described as well as } \\
\text { clearly defined responsibilities and powers. }\end{array}$ & MD3 & \\
\hline & & $\begin{array}{l}\text { 4. Officials / employees of the responsibility center (faculty / department } \\
\text { / institute) have appropriate qualifications to carry out their work }\end{array}$ & MD4 & \\
\hline & & $\begin{array}{l}\text { 5. Accountability of officials / employees is appropriate to their } \\
\text { responsibilities }\end{array}$ & MD5 & \\
\hline \multirow{5}{*}{2} & \multirow{5}{*}{$\begin{array}{l}\text { Division of the } \\
\text { organization } \\
\text { into } \\
\text { responsibility } \\
\text { centers } \\
\text { (DO) }\end{array}$} & $\begin{array}{l}\text { 1. The university divides the organizational structure into units (faculty / } \\
\text { department / institute) according to the activities nature of each unit. }\end{array}$ & DO1 & \multirow{5}{*}{$\begin{array}{c}\text { The author's proposition on } \\
\text { the basis of reference: Nguyen } \\
\text { et al. (2019), Bui (2019), } \\
\text { Hanini (2013), Muthulakshmi } \\
\text { (2014), Gharayba et al. (2011), } \\
\text { Tran (2010), Garrison \& } \\
\text { Noreen (2008), Nguyen (2006) }\end{array}$} \\
\hline & & $\begin{array}{l}\text { 2. The university clearly divides work in units (faculty / department / } \\
\text { institute) }\end{array}$ & DO2 & \\
\hline & & $\begin{array}{l}\text { 3. There is a clear description of responsibility centers (faculty / } \\
\text { department / institute) in the University }\end{array}$ & DO3 & \\
\hline & & $\begin{array}{l}\text { 4. The responsibility centers (faculty / department / institute) in the } \\
\text { University are coordinated and clear in the relationship }\end{array}$ & DO4 & \\
\hline & & $\begin{array}{l}\text { 5. Each responsibility center (faculty / department / institute) has a } \\
\text { specific type of activity }\end{array}$ & DO5 & \\
\hline \multirow{5}{*}{3} & \multirow{5}{*}{$\begin{array}{l}\text { Reward } \\
\text { (RW) }\end{array}$} & 1. Reward is done regularly & RW1 & \multirow{5}{*}{$\begin{array}{c}\text { The author's proposition on } \\
\text { the basis of reference: Nguyen } \\
\text { et al. (2019), Bui (2019), } \\
\text { Nguyen (2014), Hanini (2013), } \\
\text { Nyakuwwanika et al. (2012), } \\
\text { Gharayba et al. (2011), Pham } \\
\text { (2010) }\end{array}$} \\
\hline & & $\begin{array}{l}\text { 2. The level of reward is appropriate to the responsibilities of officials / } \\
\text { employees in responsibility centers (faculty / department / institute) }\end{array}$ & RW2 & \\
\hline & & 3. Officials / employees are satisfied with the University's reward policy & RW3 & \\
\hline & & $\begin{array}{l}\text { 4. The University relies on objective grounds and performance to reward } \\
\text { and motivate officials / employees }\end{array}$ & RW4 & \\
\hline & & 5. There is a periodic review of the reward policy in the University & RW5 & \\
\hline \multirow{4}{*}{4} & \multirow{4}{*}{$\begin{array}{l}\text { Cost and } \\
\text { income } \\
\text { allocation } \\
\quad \text { (CI) }\end{array}$} & $\begin{array}{l}\text { 1. All income related to the responsibility center (faculty / department / } \\
\text { institute) are identified and recorded }\end{array}$ & CI1 & \multirow{4}{*}{$\begin{array}{l}\text { The author's proposition on } \\
\text { the basis of reference: Nguyen } \\
\text { et al. (2019), Bui (2019), } \\
\text { Nguyen (2014), Hanini (2013), } \\
\text { Nguyen (2013), Gharayba et } \\
\text { al. (2011), Pham (2010), Lin \& } \\
\text { Yu (2002) }\end{array}$} \\
\hline & & $\begin{array}{l}\text { 2. All cost related to the responsibility center (faculty / department / } \\
\text { institute) are identified and recorded }\end{array}$ & CI2 & \\
\hline & & $\begin{array}{l}\text { 3. There is a clear system for comparing incomes and costs at } \\
\text { responsibility centers (faculty / department / institute) throughout the } \\
\text { University }\end{array}$ & $\mathrm{CI} 3$ & \\
\hline & & $\begin{array}{l}\text { 4. There is a clear policy on indirect cost distribution / management costs } \\
\text { for responsibility centers (faculty / department / institute) }\end{array}$ & CI4 & \\
\hline
\end{tabular}




\begin{tabular}{|c|c|c|c|c|}
\hline & & $\begin{array}{l}\text { 5. There is a clear system for identifying and allocating costs and } \\
\text { incomes in the university. }\end{array}$ & CI5 & \\
\hline \multirow{4}{*}{5} & \multirow{4}{*}{$\begin{array}{l}\text { Estimation } \\
\quad(\mathrm{EM})\end{array}$} & $\begin{array}{l}\text { 1. The operational budget estimation is made in relation to all } \\
\text { responsibility centers (faculty / department / institute) separately. }\end{array}$ & EM1 & \multirow{4}{*}{$\begin{array}{l}\text { The author's proposition on } \\
\text { the basis of reference: Nguyen } \\
\text { et al. (2019), Bui (2019), Guan } \\
\& \text { Lau (2018), Hanini (2013), } \\
\text { Nguyen (2013), Pham (2010), } \\
\text { Lin \& Yu (2002) }\end{array}$} \\
\hline & & $\begin{array}{l}\text { 2. The operational budget estimation at the responsibility centers (faculty } \\
\text { / department / institute) is made annually for activities. }\end{array}$ & EM2 & \\
\hline & & $\begin{array}{l}\text { 3. The university organizes training of officials / employees in } \\
\text { responsibility centers (faculty / department / institute) and encourages } \\
\text { them to achieve operational goals at responsibility centers (faculty / } \\
\text { department / institute) }\end{array}$ & EM3 & \\
\hline & & $\begin{array}{l}\text { 4. All officers / employees in responsibility centers (faculty / department } \\
\text { / institute) are involved in making the center's cost estimation according } \\
\text { to their work. }\end{array}$ & EM4 & \\
\hline \multirow{4}{*}{6} & \multirow{4}{*}{$\begin{array}{l}\text { Estimation and } \\
\text { Reality } \\
\text { (ER) }\end{array}$} & $\begin{array}{l}\text { 1. Comparison of the actual performance with the planned performance } \\
\text { of the responsibility centers facilitates communication between } \\
\text { administrative levels. }\end{array}$ & ER1 & \multirow{4}{*}{$\begin{array}{l}\text { The author's proposition on } \\
\text { the basis of reference: Nguyen } \\
\text { et al. (2019), Bui (2019), Tran } \\
\text { (2015), Hanini (2013), Hoang } \\
\text { (2010) }\end{array}$} \\
\hline & & $\begin{array}{l}\text { 2. Comparison of the actual and planned implementation of officials / } \\
\text { employees in the responsibility centers (faculty / department / institute) } \\
\text { helps assess the performance of officials / employees }\end{array}$ & ER2 & \\
\hline & & $\begin{array}{l}\text { 3. Comparison of the actual and planned implementation of officials / } \\
\text { employees in the responsibility centers (faculty / department / institute) } \\
\text { to provide appropriate information at appropriate times. }\end{array}$ & ER3 & \\
\hline & & $\begin{array}{l}\text { 4. Comparison of the actual and planned implementation of officials / } \\
\text { employees in the responsibility centers (faculty / department / institute) } \\
\text { to determine the difference, the results and determine who is responsible. }\end{array}$ & ER4 & \\
\hline \multirow{6}{*}{7} & \multirow{6}{*}{$\begin{array}{l}\text { Report } \\
\text { (RP) }\end{array}$} & $\begin{array}{l}\text { 1. Reports of responsibility centers (faculty / department / institute) are } \\
\text { prepared to measure the performance of the responsibility center. }\end{array}$ & RP1 & \multirow{6}{*}{$\begin{array}{l}\text { The author's proposition on } \\
\text { the basis of reference: Nguyen } \\
\text { et al. (2019), Bui (2019), Tran } \\
\text { (2015), Hanini (2013), Hoang } \\
\text { (2010), Nguyen et al. (2020) }\end{array}$} \\
\hline & & $\begin{array}{l}\text { 2. Managers and officers / employees of responsibility centers (faculty / } \\
\text { department / institute) are involved in designing the report pattern of unit } \\
\text { for performance evaluation }\end{array}$ & RP2 & \\
\hline & & $\begin{array}{l}\text { 3. The report related to the responsibility center (faculty / department / } \\
\text { institute) is interested in financial aspects }\end{array}$ & RP3 & \\
\hline & & $\begin{array}{l}\text { 4. Reports related to the center of responsibility (faculty / department / } \\
\text { institute) are designed on both financial and non-financial aspects such } \\
\text { as: internal processes, students, finance, study and development, etc. }\end{array}$ & RP4 & \\
\hline & & $\begin{array}{l}\text { 5. Reports measure the performance of each responsibility center (faculty } \\
\qquad / \text { department / institute) separately }\end{array}$ & RP5 & \\
\hline & & $\begin{array}{l}\text { 6. The information of the report is connected to the officers / employees } \\
\text { that are responsible for that information }\end{array}$ & RP6 & \\
\hline \multirow{4}{*}{8} & \multirow{4}{*}{$\begin{array}{l}\text { School council } \\
\quad(\mathrm{SC})\end{array}$} & $\begin{array}{l}\text { 1. Resolution on the university 's goals, directions and plans, supervise } \\
\text { the University's activities within the scope of its functions and duties. }\end{array}$ & $\mathrm{SC} 1$ & \multirow{4}{*}{$\begin{array}{l}\text { The author's proposition on } \\
\text { the basis of expert interviews. }\end{array}$} \\
\hline & & $\begin{array}{l}\text { 2. The School Council is oriented to develop and participate in the } \\
\text { process of supervising the recruitment, management and use of the } \\
\text { University's staff, officers and employees. }\end{array}$ & $\mathrm{SC} 2$ & \\
\hline & & $\begin{array}{l}\text { 3. The School Council participates in the process of introducing the } \\
\text { Rector, Vice-Rector and School Council personnel and supervise the } \\
\text { appointment process according to the regulations. }\end{array}$ & $\mathrm{SC} 3$ & \\
\hline & & $\begin{array}{l}\text { 4. The School council supervises, inspects and urges the implementation } \\
\text { of the School Council's resolutions }\end{array}$ & $\mathrm{SC} 4$ & \\
\hline 9 & $\begin{array}{l}\text { University } \\
\text { autonomy } \\
\text { (UA) }\end{array}$ & $\begin{array}{l}\text { 1. The University has the right to decide on issues related to conditio } \\
\text { ns of employment, salaries, use of human resources, appointment and } \\
\text { dismissal of titles of lecturers and staff. }\end{array}$ & UA1 & $\begin{array}{l}\text { The author's proposition on } \\
\text { the basis of expert interviews. }\end{array}$ \\
\hline
\end{tabular}




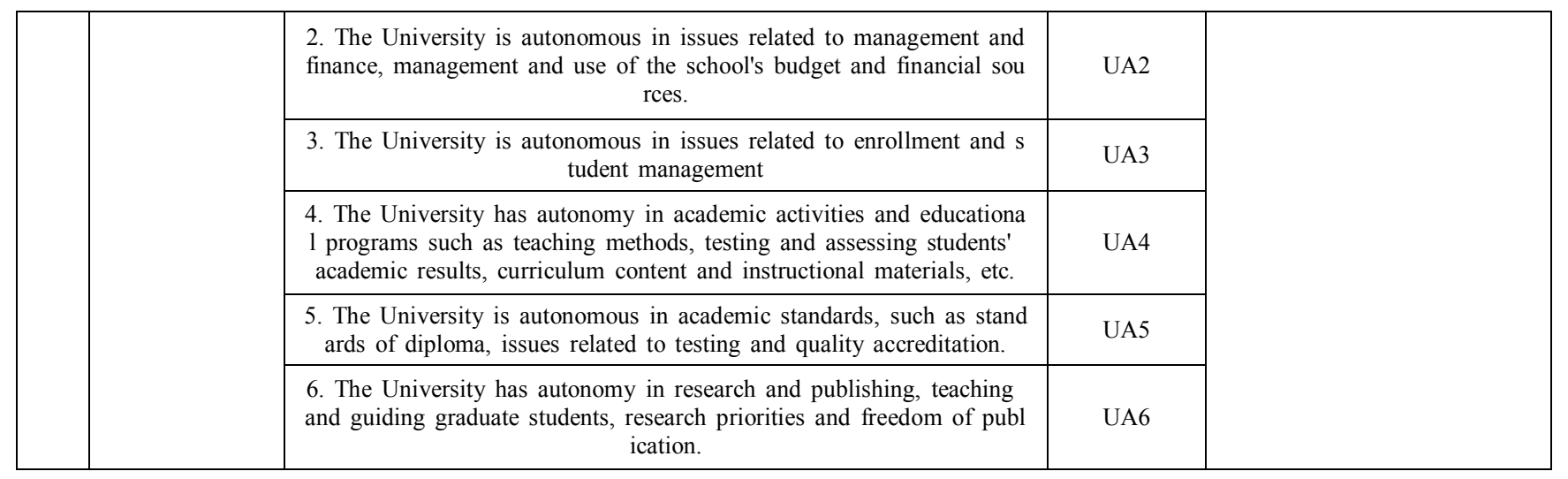

\subsection{Data Collection}

In order to evaluate the factors affecting responsibility accounting at public universities in Vietnam, the author use the questionnaire survey method. We sent the survey directly or through the Google Form tool to representatives of universities. The questionnaire is designed in two parts, Part 1 deals with general information on the participants and Part 2 presents the survey questions. The questions are designed around the research objectives, asking respondents' evaluation based on the Likert scale from 1 to 5. To come up with an official survey, the author went through three phases: Phase 1: based on the literature review, the author designed an initial draft questionnaire. Phase 2: 20 experts were consulted and a preliminary survey was conduct with 10 public universities in the North, Central and South of Vietnam to ensure that the questions were adequate and appropriate to the Vietnamese context and were clear and understandable by the respondents. Phase 3: an official questionnaire was designed, based on Phase 2 results; the author finalized a final complete questionnaire, which was sent to the participants.

\subsection{Methods of Data Analysis}

From the valid questionnaires collected, data were imported into Excel, as were coding variables. The data were then processed through SPSS 22.0 software going through many analyses and testing tools as follows:

\subsubsection{Descriptive Statistics and Mean Test:}

Use descriptive statistics to calculate the mean for the factors affecting RA as well as the mean test to evaluate the mean value of the factors compared to the average value of 3 , to see the influence level of the factors.

\subsubsection{Cronbach's Alpha Analysis:}

The purpose of Cronbach's Alpha analysis is to test the reliability of scales and survey data to assess the correlation between observed variables to assess whether they are closely related to each other in measuring the influence of the factors on RA. Most researchers accept Cronbach's Alpha levels of 0.8 or higher; it is usable from 0.7 to 0.8 and if the concepts in the question are new, the coefficient is just above 0.6 is acceptable. With Cronbach's Alpha level greater than or equal to 0.8 , the scale is considered a good measure; the scales are actually correlated with each other to achieve high reliability (Hoang \& Chu, 2011). EFA exploratory factor analysis: When analyzing exploratory factor analysis, researchers often care about some standards.

First, KMO coefficient (Kaiser-Meyer-Olkin) $\geq 0.5$, the significance level of Bartlett test $\leq 0.05$. KMO is a criterion used to consider the appropriateness of EFA, $0.5 \leq \mathrm{KMO} \leq$ 1 , then factor analysis is appropriate. Bartlett's Test examined the hypothesis whether there is a correlation between observed variables overall. If this test is statistically significant $(\mathrm{Sig} \leq 0.05)$, the observed variables are correlated.

Second, factor loading coefficient $>0.45$. If any observed variable has factor loading coefficient $\leq 0.45$, it will be disqualified.

Third, the scale is accepted when the total variance extracted $\geq 50 \%$ and eigenvalue is greater than 1 .

The fourth criterion is the difference in factor loading coefficient of an observed variable among factors $\geq 0.3$ to ensure the distinguishing value among factors is protected (Hoang \& Chu, 2011). According to Dinh et al. (2018), Factor loading is the norm to ensure the practical meaning of EFA, Factor loading $>0.3$ is considered to be the minimum, Factor loading $>0.4$ is considered important, $\geq$ 0.5 is considered to have practical significance.

\section{Research Results}

\subsection{Cronbach's Alpha}

In this study, the observed variables of the independent and dependent variables are selected when the Cronbach's 
Alpha coefficient is 0.6 or higher and the total correlation coefficient is greater than 0.3 . The results shown in Table 2 show that the variables in the research model are reliable.

Table 2: The Cronbach's Alpha coefficient of the independent variables and the dependent variable

\begin{tabular}{|c|c|c|}
\hline Reliability Statistics & N of Items & $\begin{array}{c}\text { Cronbach's } \\
\text { Alpha }\end{array}$ \\
\hline $\begin{array}{c}\text { 1. Management decentralization } \\
\text { (MD) }\end{array}$ & 5 & 0.871 \\
\hline $\begin{array}{c}\text { 2. Division of the organization i } \\
\text { nto responsibility centers (DO) }\end{array}$ & 5 & 0.839 \\
\hline 3. Reward (RW) & 5 & 0.910 \\
\hline 4. Cost and income allocation \\
(CI) & 5 & 0.883 \\
\hline 5. Estimation (EM) & 4 & 0.903 \\
\hline 6. Estimation and reality (ER) & 4 & 0.765 \\
\hline 7. Report (RP) & 6 & 0.923 \\
\hline 8. School council (SC) & 4 & 0.876 \\
\hline 9. University autonomy (UA) & 6 & 0.907 \\
\hline 10. The performance of RA (Y) & 3 & 0.796 \\
\hline
\end{tabular}

\subsection{Exploratory Factor Analysis (EFA)}

The results of Exploratory Factor Analysis are shown in Table 3. According to Table 3, the KMO coefficient equals to $0.684>0.5$ (greater than the minimum to ensure that EFA analysis is appropriate) and Sig level of Bartlett's test is $0.000<0.05$; it means that the variables correlatedoverall. Therefore, the EFA analysis is really meaningful. At the same time, the analysis shows that, in the above table of variance extracted according to the standard of Eigenvalue $>1$, there are nine groups of factors drawn. The total variance extracted is $72,420 \%$ (greater than $50 \%$ ). This means $72,420 \%$ of the data variance is explained by nine groups of factors.

Table 3: Some inspection criteria of Exploratory Factor Analysis for independent variables

\begin{tabular}{|c|c|c|}
\hline \multicolumn{2}{|c|}{$\begin{array}{c}\text { Kaiser-Meyer-Olkin Measure of Sampling } \\
\text { Adequacy. }\end{array}$} & $\mathbf{. 6 8 4}$ \\
\hline \multirow{3}{*}{ Bartlett's Test of Sphericity } & Approx. Chi-Square & 4424.983 \\
\cline { 2 - 3 } & df & 946 \\
\cline { 2 - 3 } & Sig. & .000 \\
\hline Total Variance Explained & & 72.420 \\
\hline
\end{tabular}

As regards Factor Loading in groups, according to Hair et al. (2010), in order to ensure the practical significance of EFA, Factor Loading $>0.3$ is considered to be a minimum, Factor Loading $>0.4$ is considered important, and Factor Loading $\geq 0.5$ is considered to be of practical significance. As a result, when using the Varimax rotation to obtain the best load coefficient, we obtained nine groups of factors including report (six variables), university autonomy (six variables), reward (five variables), management decentralization (five variables), cost and income allocation (five variables), division of the organization into responsibility centers (five variables), estimation (four variables), school council (four variables), and estimation and reality (four variables), as detailed in Table 4 below.

For the performance of RA at public universities in Vietnam, with three observed variables, the results of factor analysis are shown in Table 5. According to Table 5, we have KMO coefficient $=0.708>0.5$ (greater than the minimum to ensure that EFA analysis is appropriate) and the Sig level of Bartlett's test is $0.000<0.05$ meaning that the variables correlated overall. Therefore, the EFA analysis is really meaningful.

Table 4: Factor rotation matrix

\begin{tabular}{|c|c|c|c|c|c|c|c|c|c|}
\hline & \multicolumn{9}{|c|}{ Component } \\
\hline & 1 & 2 & 3 & 4 & 5 & 6 & 7 & 8 & 9 \\
\hline $\mathrm{RP} 1$ & .904 & & & & & & & & \\
\hline RP6 & .865 & & & & & & & & \\
\hline $\mathrm{RP} 3$ & .846 & & & & & & & & \\
\hline RP5 & .833 & & & & & & & & \\
\hline $\mathrm{RP} 4$ & .816 & & & & & & & & \\
\hline $\mathrm{RP} 2$ & .756 & & & & & & & & \\
\hline UA5 & & .865 & & & & & & & \\
\hline UA6 & & .857 & & & & & & & \\
\hline UA3 & & .821 & & & & & & & \\
\hline UA2 & & .802 & & & & & & & \\
\hline
\end{tabular}




\begin{tabular}{|c|c|c|c|c|c|c|c|c|}
\hline UA4 & .793 & & & & & & & \\
\hline UA1 & .780 & & & & & & & \\
\hline RW2 & & .869 & & & & & & \\
\hline RW3 & & .855 & & & & & & \\
\hline RW1 & & .847 & & & & & & \\
\hline RW5 & & .785 & & & & & & \\
\hline RW4 & & .773 & & & & & & \\
\hline MD4 & & & .868 & & & & & \\
\hline MD3 & & & .803 & & & & & \\
\hline MD1 & & & .764 & & & & & \\
\hline MD2 & & & .715 & & & & & \\
\hline MD5 & & & .686 & & & & & \\
\hline CI1 & & & & .770 & & & & \\
\hline CI4 & & & & .762 & & & & \\
\hline $\mathrm{CI} 5$ & & & & .731 & & & & \\
\hline $\mathrm{Cl} 2$ & & & & .728 & & & & \\
\hline $\mathrm{Cl} 3$ & & & & .725 & & & & \\
\hline DO5 & & & & & .823 & & & \\
\hline $\mathrm{DO} 2$ & & & & & .786 & & & \\
\hline DO4 & & & & & .753 & & & \\
\hline DO1 & & & & & .741 & & & \\
\hline DO3 & & & & & .731 & & & \\
\hline EM3 & & & & & & .924 & & \\
\hline EM1 & & & & & & .907 & & \\
\hline EM2 & & & & & & .902 & & \\
\hline EM4 & & & & & & .719 & & \\
\hline $\mathrm{SC} 1$ & & & & & & & .906 & \\
\hline $\mathrm{SC} 2$ & & & & & & & .880 & \\
\hline $\mathrm{SC} 3$ & & & & & & & .840 & \\
\hline $\mathrm{SC} 4$ & & & & & & & .739 & \\
\hline ER1 & & & & & & & & .868 \\
\hline ER2 & & & & & & & & .701 \\
\hline ER4 & & & & & & & & .669 \\
\hline ER3 & & & & & & & & .664 \\
\hline
\end{tabular}

Table 5: Some inspection criteria of Exploratory Factor Analysis for dependent variable

\begin{tabular}{|c|c|c|}
\hline \multicolumn{2}{|c|}{ Kaiser-Meyer-Olkin Measure of Sampling Adequacy. } & .708 \\
\hline \multirow{3}{*}{ Bartlett's Test of Sphericity } & Approx. Chi-Square & 115.896 \\
\cline { 2 - 3 } & $\mathrm{df}$ & 3 \\
\cline { 2 - 3 } & Sig. & .000 \\
\hline Total Variance Explained & & 71.222 \\
\hline
\end{tabular}

In the above extracted variance table, according to the standard of Eigenvalue $>1$, there is one factor drawn. The total variance extracted is $71.222 \%$ (greater than $50 \%$ ), ie $71.222 \%$ of the data variance is explained by this factor. In the factor matrix, the results of the factor analysis show that there is one factor of the performance of RA at public universities in Vietnam and nine factors affecting the 
performance of RA at these universities, all of which are reliable and statistically significant (see Table 6).

Table 6: Factor matrix

\begin{tabular}{|c|c|}
\hline & Component \\
\cline { 2 - 2 } & $\mathbf{1}$ \\
\hline Y3 & .852 \\
\hline Y1 & .851 \\
\hline Y2 & .828 \\
\hline
\end{tabular}

\subsection{Regression Analysis}

To perform regression analysis, the authors calculated the mean value of the group of factors; Table 7 shows the results. From the regression results, it can be seen that all independent variables actually affect the dependent variable Y (this is arrived at through T-test with the Sig level of the Test being less than $1 \%, 5 \%$ or $10 \%)$. In particular, the independent $\mathrm{SC}$ variable has Sig level $=0.304>0.05 \mathrm{so}$, the $\mathrm{SC}$ variable is not statistically significant. In other words, the $\mathrm{SC}$ variable has no effect on $\mathrm{Y}$.

Table 7: The results of regression analysis

\begin{tabular}{|c|c|c|c|c|c|c|c|}
\hline \multirow{2}{*}{ Model } & \multicolumn{2}{|c|}{ Unstandardized Coefficients } & \multirow{2}{*}{$\frac{\text { Standardized Coefficients }}{\text { Beta }}$} & \multirow{2}{*}{$\mathbf{t}$} & \multirow{2}{*}{ Sig. } & \multicolumn{2}{|c|}{ Collinearity Statistics } \\
\hline & B & Std. Error & & & & Tolerance & VIF \\
\hline (Constant) & -1.839 & .497 & & -3.702 & .000 & & \\
\hline MD & .188 & .084 & .160 & 2.231 & .028 & .696 & 1.437 \\
\hline DO & .255 & .083 & .194 & 3.078 & .003 & .898 & 1.114 \\
\hline RW & .151 & .057 & .183 & 2.659 & .009 & .759 & 1.317 \\
\hline $\mathrm{CI}$ & .229 & .067 & .269 & 3.422 & .001 & .580 & 1.723 \\
\hline EM & .153 & .055 & .178 & 2.803 & .006 & .891 & 1.122 \\
\hline ER & .240 & .088 & .181 & 2.722 & .007 & .811 & 1.232 \\
\hline $\mathrm{RP}$ & .099 & .050 & .131 & 1.983 & .050 & .820 & 1.219 \\
\hline $\mathrm{SC}$ & .053 & .051 & .063 & 1.033 & .304 & .972 & 1.028 \\
\hline UA & .201 & .056 & .223 & 3.587 & .000 & .923 & 1.084 \\
\hline
\end{tabular}

The problem of multicollinearity (a serious defect of the model in the case of survey data) does not appear in this model. Specifically, the variance inflation factors VIF are less than 10 (the level where multicollinearity is serious problem). Besides that, Anova test results of the suitability of the regression function through statistics $F=17.914$ shows that the model is really suitable (Sig level of the test is very small, Sig. $=0.000$ ).

Thus, based on the regression results table (Table 7), we have a regression equation for the factors affecting the performance of RA at public universities in Vietnam as follows:

\section{$\mathrm{Y}=-1.839+0.188 * \mathrm{MD}+0.255 * \mathrm{DO}+0.151 * \mathrm{RW}+$ $0.229 * \mathrm{CI}+0.153 * \mathrm{EM}+0.240 * \mathrm{ER}+0.099 * \mathrm{RP}+$ $0.201 * \mathrm{UA}$}

Moreover, through the standardized beta column, we can also see that CI has the strongest impact on the dependent variable Y (standardized beta is 0.269 ), followed by UA and DO (beta standardized are 0.223 and 0.194 , respectively). The lowest impact on the dependent variable is the RP factor with a standardized beta of only 0.131 .
Other factors such as MD, RW, EM, and ER have similar levels of impact.

\section{Discussion and Policy Implications}

From the regression result, all factor groups (MD, DO, RW, CI, EM, ER, RP, UA) have an influence on Y. Meanwhile, CI shows the strongest effect, followed by UA, DO, RW and ER, while other factor groups such as EM, MD and RP produce unimportant impacts. Therefore, the authors recommend several solutions for completing responsibility accounting as follows:

Cost and income allocation (CI): Universities need to strictly control the incomes of the responsibility centers (faculty/department/institute) to ensure an equitable distribution of operating funds to the responsibility centers. In addition, responsibility centers should be required to have specific documents and spending plans to track expenses and to avoid wasting operating funds of the universities. This control will help the universities determine the responsibilities of each center with direct costs and administrative costs, incomes to limit overlap of 
responsibilities and more accurate, more suitable cost calculation.

University autonomy (UA): Autonomy is the right of universities to take their own decisions regarding university development issues without being bound by external regulations. Therefore, the Government and the Ministry of Education and Training should thoroughly decentralize the universities: (1) Autonomy and self-responsibility for the organization, management system of the university so that the university has full autonomy in organization and personnel, as well as be responsible to the state agencies for the decisions on the organization and personnel of the university; (2) Autonomy and financial self-responsibility through decentralization to universities so they are allowed to expand incomes and self-conduct expenditure, selfpromulgating internal spending regulations, selfimplementation of financial statements accountability between levels at the university, self-organizing control activities and financial disclosure; (3) Autonomy and selfresponsibility in training activities such as autonomy and self-responsibility to society for training plan, autonomy and social responsibility in enrollment; (4) Autonomy and self-responsibility for examination and evaluation means that each university decides for itself how to test and evaluate lecturers and students, thereby gradually diversifying teaching, learning and research methods to build the reputation of the university.

Divide the organization into responsibility centers $(\mathrm{DO})$ : On the basis of mission and vision, short-term and longterm goals need to implement restructuring the organization into different centers of responsibility based on the nature of each university's operations in a proactive manner and flexible management. This division will limit the status of work and responsibility shifting among the responsibility centers in the university; responsibility centers include the revenue responsibility center, the cost responsibility center, the profitability center and the investment responsibility center.

Reward (RW): Universities should have an incentive policy that is timely and commensurate with the results achieved at the responsibility centers. At the same time, the reward policy should ensure the objectivity and comprehensiveness; it is necessary to supplement specific reward regulations suitable to the duties of each employee who is not a lecturer or a manager. This policy should be reviewed periodically, through consultation, amendment and policy supplements to encourage and reward in a manner suitable to the development process of the university. This way, the reward is effective and encourages officials and employees to strive to improve their results.

Estimation and reality (ER): In order to evaluate the results achieved as well as the responsibilities of management officials at responsibility centers, universities need to make detailed estimation for each responsibility center to control and measure the achieved results of each responsibility center. An objective assessment is necessary to clearly identify the responsibilities of the unwanted differences, which belong to specific officials and employees to take appropriate measures and assessments. It should be done regularly and continuously to respond to information for decision making timely.

\section{Conclusion}

This study has shown that the performance of RA at public universities in Vietnam is influenced by the factors of decentralization of management, division of the organization into responsibility centers, reward, cost and income allocation, estimation, evaluation of the results achieved between the estimation compared with reality, release of reports and university autonomy. Among the factors mentioned above, cost and income allocation, university autonomy, division of the organization into responsibility centers, reward and evaluation of results achieved between estimation and reality are factors that have strong impacts. Estimation, management decentralization and report are influential, but not significant. It is noteworthy that the School Council at public universities in Vietnam has no effect on the performance of RA.

\section{References}

Belkaoui, A. (1981). The relationship between self-disclosure style and attitudes to responsibility accounting. Accounting, Organizations and Society, 6(4), 281-289. https://doi.org/10.1016/0361-3682(81)90008-8.

Bui, T. X. H. (2019). A Study on factors affecting responsibility accounting at Quy Nhon University (Master's thesis). Quy Nhon University, Binh Dinh, Vietnam.

Dinh, P. H., Vo, V. N., \& Tran, P. (2018). Quantitative research in Accounting - Auditing. Hanoi, Vietnam: Financial Publishing House.

Fowzia, R. (2011). Use of responsibility accounting and measure the satisfaction levels of service organizations in Bangladesh. International Review of Business Research Papers, 7(5), 5367.

Garrison, R. H., \& Noreen, E. W. (2008). Managerial Accounting (11th ed.). New York, NY: McGraw-Hill Companies.

Gharayba, F. A., Debie, M. A., \& Nassar, M. A. (2011). The extent of applying the elements of responsibility accounting in the Industrial Shareholding Companies and effect on the Company's Profitability and Operational efficiency. Administrative Sciences, 38(1), 219- 234.

Guan, L. F., \& Lau, W. Y. (2018). Triffin Dilemma and International Monetary System: Evidence from Pooled Mean 
Group Estimation. Journal of Asian Finance, Economics and Business, 5(2), 5-14. https://doi.org/10.13106/jafeb.2018.vol5.no2.5.

Hair, J. F., Andreson, R. E., Tahtam, R. L., \& Black, C. W. (2010). Multivariate Data Analysis. Upper Saddle River, NJ: Prentice Hall International Inc.

Hanini, A. E. (2013). The extent of implementing responsibility accounting features in the Jordanian banks. European Journal of Business and Management, 5(1), 217-229.

Hoque, Z., \& James, W. (2000). Linking balanced scorecard measures to size and market factors: impact on organizational performance. Journal of Management Accounting Research, 12(1), 1-17. https://doi.org/10.2308/jmar.2000.12.1.1.

Hoang, V. T. (2010). Organize management accounting with strengthening management of business activities in Vietnam construction enterprises. Hanoi, Vietnam: National Economics University Publishing House.

Hoang, T., \& Chu, N. M. N. (2011). Applied Statistics in SocialEconomic Analysis. Hanoi, Vietnam: Labour and Social Publishing House.

Horngren, C. T., Foster, G., Datar, S. M., Rajan, M., Ittner, C., \& Baldwin, A. A. (2010). Cost accounting: A managerial emphasis. Issues in Accounting Education, 25(4), 789-790.

Joda, A. M., Sheikh, E. Y., \& Sbo, S. S. (2009). The extent of applying responsibility accounting in the Jordanian hotels. Zarqa Journal for Research and Studies, 9(2), 23-49. Retrieved from

http://zu.edu.jo/en/Deans/ResearchDeanship/JournalOfZarqaU niversity.aspx? $\mathrm{id}=65$.

Lin, Z. J., \& Yu, Z. (2002). Responsibility cost control system in China: a case of management accounting application. Management Accounting Research, 13(4), 447-467. https://doi.org/10.1006/mare.2002.0200.

Muthulakshmi, P. (2014). Examining the role of responsibility accounting in organization structure, International Journal of Scientific Research, 3(4), 1-3. https://doi.org/10.15373/22778179/APR2014/209.

Nguyen, H. P. (2014). Responsibility accounting for construction corporations under the Ministry of Transport. Ho Chi Minh, Vietnam: University of Economics Ho Chi Minh City.
Nguyen, T. M. P. (2013). Building responsibility accounting model in Vietnam dairy manufacturing enterprises. Hanoi, Vietnam: National Economics University.

Nguyen, N. Q. (2006). Perfecting cost management accounting in Vietnamese enterprises. Hanoi, Vietnam: National Economics University Publisher House.

Nguyen, N., Nguyen, T., \& Pham, D. (2019). Factors affecting the responsibility accounting in Vietnamese firms: A case study for livestock food processing enterprises. Management Science Letters, $9(9), \quad 1349-1360$. https://doi.org/10.5267/j.msl.2019.5.015.

Nguyen, T. L. H., Nguyen, T. T. H., Nguyen, T. T. H, Le, T. H. A., \& Nguyen, V. C. (2020). The Determinants of Environmental Information Disclosure in Vietnam Listed Companies. Journal of Asian Finance, Economics and Business, 7(2), 21-31. https://doi.org/10.13106/jafeb.2020.vol7.no2.21.

Nyakuwanika, M., Gumisai, J., Gutu, S., Frank, T., \& Clainos, C. (2012). An analysis of Effective Responsibility Accounting System Strategies in the Zimbabwean Health Sector. Research Journal of Finance and Accounting, 3(8), 86-92. https://www.iiste.org/Journals/index.php/RJFA/article/view/28 $27 / 2853$

Okoye, E. R., Ekwezia N., \& Ngozi, I. (2009). Improvement of managerial performance in Manufacturing Organization - An application of responsibility accounting. Journal of the Management Sciences, 9(1), 1-17.

Pham, V. D. (2010). Organize the accounting reporting system to assess the division of responsibility in commercial enterprises in Vietnam. Ho Chi Minh, Vietnam: University of Economics Ho Chi Minh City.

Shields, M. D. (1995). An empirical analysis of firms' implementation experiences with activity-based costing. Journal of Management Accounting Research, 7(1), 148-165.

Tran, T. T. (2015). Responsibility accounting research in Vietnamese cement manufacturing enterprises. Hanoi, Vietnam: National Economics University.

Tran, V. T. (2010). Develop a system of management responsibility assessment reports in listed companies in Vietnam. Ho Chi Minh, Vietnam: University of Economics Ho Chi Minh City. 